\title{
BUTORPHANOL TARTRATE: \\ 2. SAFETY AND EFFICACY IN BALANCED ANAESTHESIA*
}

\author{
Allen B. Dobkin, Hernando Y. Arandia, Peter H. Byles, \\ Benjamin F. Africa, Frank S. Caruso and Robert J. Noveck
}

Butorphanol tartrate has been shown to provide adequate relief of severe post-operative pain for at least four hours when administered to adults intramuscularly in a dose of 2 to $4 \mathrm{mg}$. Morphine sulphate 10 to $15 \mathrm{mg}$, meperidine 80 $\mathrm{mg} / 70 \mathrm{~kg}$ and pentazocine 30 to $60 \mathrm{mg}$ have a similar effect. ${ }^{1-4}$ In normal volunteers, respiratory depression and the suppression of the respiratory stimulating response to carbon dioxide inhalation appears to be less with butorphanol tartrate than with morphine sulphate. ${ }^{5}$ When butorphanol tartrate 3 mg or morphine sulphate $15 \mathrm{mg}$ was given intravenously to consenting patients under double-blind conditions, there was no appreciable elevation in plasma histamine with either. ${ }^{6}$ Finally, in a single blind study of subjects undergoing diagnostic cardiac catheterization, the intravenous injection of butorphanol tartrate $0.02 \mathrm{mg} / \mathrm{kg}$, or morphine sulphate $0.10 \mathrm{mg} / \mathrm{kg}$, directly through a catheter inserted into the heart of consenting patients with suspected coronary heart disease, revealed that morphine sulphate tended to decrease stroke index, lowered left ventricular systolic blood pressure, and lowered left ventricular volume, while butorphanol tartrate tended to augment these parameters slightly. This cardiovascular study indicated that the new compound is safe even in patients with severe ischaemic heart disease. ${ }^{7}$ In addition, the multidose administration of butorphanol tartrate over a period of 12 to 18 hours for relief of severe pain had no appreciable effect on the cardiorespiratory system. ${ }^{8}$

The objective of the present study was to evaluate the safety and efficacy of repeated intravenous injections of butorphanol tartrate in combination with hypnotics and muscle relaxants for balanced anaesthesia in patients requiring major abdominal operations.

\section{Clinical Management \\ METHODS}

Informed written consent was obtained from adult patients the day before they underwent elective major abdominal surgery. Then, a venous blood sample was drawn for baseline serum transaminases, bilirubin, alkaline phosphatase, creatinine and blood urea nitrogen, albumin and total protein, in addition to routine laboratory studies which included chest and abdominal X-rays and an electrocardiogram. An anaerobic arterial blood sample was also taken to determine $\mathrm{pH}$, $\mathrm{Pa}_{\mathrm{CO}_{2}}, \mathrm{~Pa}_{\mathrm{O}_{2}}, \mathrm{Sa}_{\mathrm{O}_{2}}$, haemoglobin and haematocrit. Fifty-three patients, free from severe renal, hepatic or cardiorespiratory disease, including 38 non-pregnant females, were selected for this study. Vital statistics for these patients are shown in

"From the Department of Anesthesiology, State University of New York, Upstate Medical Center, State University Hospital, Syracuse, New York, 13210, U.S.A. 
TABLE I

Vital Statistics of Patients

\begin{tabular}{|c|c|c|c|c|c|c|}
\hline & \multicolumn{4}{|c|}{ Age (years) } & \multirow{2}{*}{$\begin{array}{r}\text { Median } \\
\text { (range) }\end{array}$} & \multirow[b]{2}{*}{ Tota } \\
\hline & $21-45$ & $45-60$ & $61-75$ & $>75$ & & \\
\hline \multirow[t]{2}{*}{ No. of patients } & $\begin{array}{l}20 \\
38\end{array}$ & $\begin{array}{l}22 \\
42\end{array}$ & $\begin{array}{r}8 \\
15\end{array}$ & $\begin{array}{l}3 \\
6\end{array}$ & $51(21-87)$ & 53 \\
\hline & \multicolumn{2}{|c|}{ Sex } & \multicolumn{2}{|c|}{ Race } & \multicolumn{2}{|c|}{ Bodyweight $(\mathrm{kg})$} \\
\hline $\begin{array}{l}\text { No. of patients } \\
\%\end{array}$ & $\begin{array}{c}\text { Male } \\
15 \\
28\end{array}$ & $\begin{array}{c}\text { Female } \\
58 \\
72\end{array}$ & $\begin{array}{c}\text { Caucasian } \\
50 \\
94\end{array}$ & $\begin{array}{c}\text { Non-Caucasian } \\
3 \\
6\end{array}$ & $\begin{array}{l}\text { Mean (range) } \\
69(44-109)\end{array}$ & $\begin{array}{l}\text { Mediaǹ } \\
64\end{array}$ \\
\hline
\end{tabular}

Table I. Five of the patients had heart disease of whom two had a previous myocardial infarction. Two patients had marked pulmonary insufficiency and one patient had obstructive jaundice.

Fifty-one patients received diazepam $5 \mathrm{mg}$ or $10 \mathrm{mg}$, atropine $0.2 \mathrm{mg}$ and scopolamine $0.2 \mathrm{mg}$ intramuscularly about one hour before induction of anaesthesia. One patient received diazepam $5 \mathrm{mg}$ and atropine $0.4 \mathrm{mg}$, and one other received the atropine and scopolamine without diazepam.

Following routine preparation including the recording of vital signs and electrocardiogram tracing (lead II), an infusion of lactated Ringer's solution was begun through a large plastic cannula inserted into an accessible vein in a hand or forearm. Butorphanol tartrate $(3 \mathrm{mg})$ was injected intravenously. Induction of anaesthesia was completed within two minutes with a sleep-dose of thiopentone ( $2 \mathrm{mg}$ to $4 \mathrm{mg} / \mathrm{kg}$ ) and pancuronium approximately $0.1 \mathrm{mg} / \mathrm{kg}$. The lungs were then ventilated manually with 100 per cent oxygen for about three minutes, after which a tracheal tube was inserted orally and attached to a mechanical respirator set to deliver a tidal volume of approximately $8 \mathrm{ml} / \mathrm{kg}$ of a mixture of $2: 1$ nitrous oxide: oxygen at a cycling rate of 12 to 15 per minute. Supplementary doses of butorphanol tartrate $(0.5 \mathrm{mg}$ to $1.0 \mathrm{mg}$ ) were given when deemed necessary, as indicated usually by a rising blood pressure, and additional pancuronium was given usually in doses of one $\mathrm{mg}$ to maintain adequate muscle relaxation for the surgical procedure. The mean duration of all operations was 195 minutes with a range of 55 to 465 minutes.

At the end of the operation the effect of the muscle relaxant was reversed with atropine and neostigmine (1:2) if adequate spontaneous respiration did not resume promptly, as verified by a Wright respirometer. If respiration was again inadequate in the recovery room and the patient was very drowsy, naloxone was given in a dose of $0.4 \mathrm{mg}$. If severe pain developed early (within 30 minutes) in the recovery room, additional butorphanol tartrate was given.

Clinical Monitoring and Follow-up

As soon as the patient was ready for surgery, a plastic cannula was inserted percutaneously into the radial artery and attached to a strain-gauge and a calibrated oscilloscope ${ }^{\circ}$ to display the intra-arterial blood pressure visually. A three-

'Datascope 850, Type $\mathrm{P}_{2}$ (Pressure Module). 
way stopcock was fitted to the cannula for arterial blood sampling for serial measurement of blood gases and $\mathrm{pH}$. The cannula was flushed continuously with heparinized saline. The electrocardiogram was displayed continuously on an oscilloscope which was attached to an electrocardiograph, so that permanent tracings could be made at 30 - to 60 -minute intervals or when an abnormal configuration appeared. A Wright respirometer was used to check pulmonary ventilation at intervals during the operation.

Post-operatively, in the recovery room, each patient was given oxygen either by nasal catheter or with a Venturi-mask which provided approximately 30 per cent oxygen. Arterial blood pressure, electrocardiogram and pulmonary ventilation were monitored for at least two hours while the patient was kept under direct surveillance to ensure a complete record of recovery from anaesthesia. The recording equipment was then removed.

On the following day, the patient was visited by an investigator to check the response to anaesthesia and the vital signs. A questionnaire was completed to record the patient's evaluation of the anaesthetic and what was remembered about the day of the operation. Venous and arterial blood samples were again drawn for follow-up laboratory tests and blood gas measurements.

\section{REsults AND Discussion}

Most of the patients ( 91 per cent) were drowsy prior to induction of anaesthesia, and the majority ( 71 per cent) appeared to be somewhat apprehensive or excited in spite of premedication. We have found this response to be usual before major surgery ${ }^{\ominus}$ ( see Table II).

Following the administration of the first dose of butorphanol tartrate intravenously ( $1.5 \mathrm{mg}$ in one patient, $3 \mathrm{mg}$ in 51 , and $4 \mathrm{mg}$ in one), all patients became drowsy and most stated that they felt good. Completion of induction of anaesthesia with thiopentone and pancuronium and, then, oral intubation, were smooth in all cases. Maintenance of anaesthesia with 2:1 nitrous oxide:oxygen and periodic supplementation with butorphanol tartrate and pancuronium, along with mechanically controlled respiration, were also smooth in all cases. The total doses and the ranges of parenteral medication are shown in Table III.

Unless the patient was anaemic at the outset (haemoglobin $<10$ grams per cent), lactated Ringer's solution and 5 per cent dextrose in water were administered by drip infusion until surgical blood loss exceeded $500 \mathrm{ml}$. Whole blood or packed red blood cells were then given. Otherwise, a whole blood transfusion was started at the beginning of the operation. None of the patients developed marked or persistent hypotension and no other drugs were administered except, in a few instances, an antibiotic, cefazolin sodium. In patients undergoing aorticfemoral bypass, heparin and mannitol were administered intravenously, usually shortly before the aorta was clamped.

\section{Cardiorespiratory Effects}

Arterial blood pressure was usually somewhat elevated throughout the operation, but part of the elevation was undoubtedly due to the higher pressure that is 
TABLE II

Assessment of Premedication

\begin{tabular}{lccccc}
\hline \hline Symptoms & None & Slight & Moderate & Marked & $\begin{array}{c}\text { Total } \\
\text { patients }\end{array}$ \\
\hline Drowsy & $1(2 \%)$ & $(8 \%)$ & $47(89 \%)$ & $1(2 \%)$ & 53 \\
Apprehensive & $15(28 \%)$ & $31(58 \%)$ & $5(9 \%)$ & $2(4 \%)$ & 53 \\
Excited & $37(70 \%)$ & $13(24 \%)$ & $3(6 \%)$ & 0 & 53 \\
\hline
\end{tabular}

TABLE III

I.V. Medications for Anaesthesia

\begin{tabular}{lc}
\hline \hline Drugs & Mean dose in mg (range) \\
\hline Butorphanol tartrate $(0.1 \%)$ & $7(2-12)$ \\
Thiopentone $(2.5 \%)$ & $165(100-350)$ \\
Pancuronium $(0.1 \%)$ & $7.4(5-10)$ \\
\hline
\end{tabular}

recorded from the arterial cannula, when compared to the initial blood pressure taken by auscultation with a mercury manometer attached to a Riva-Rocci cuff. ${ }^{10}$ In one patient, marked elevation of the blood pressure occurred ( $>30$ per cent). Chlorpromazine $(2 \mathrm{mg}$ ) was given intravenously to reduce it. The pulse rate was quite stable throughout the operations (Table IV).

The electrocardiogram was normal before, during and after anaesthesia in 43 ( 81 per cent) of the patients. Two patients had non-specific electrocardiogram abnormalities during the time that recordings were taken, and one had a sinus arrhythmia throughout. These were probably unrelated to the anaesthesia and surgery. Of the other seven patients, three had ECG abnormalities during their operation: one had sinus bradycardia and two had premature ventricular contractions at varying intervals. The others had normal ECG before and during the operations and developed occasional premature ventricular contractions and bradycardia postoperatively. None of these ECG changes were attributed to the anaesthetic or to hypoxaemia.

TABLE IV

Mean Vital Signs During Balanced Anaesthesia with Butorphanol Tartrate, Thiopentone, Pancuronium and $\mathrm{N}_{2} \mathrm{O}$

\begin{tabular}{|c|c|c|c|c|c|c|c|}
\hline & $\mathrm{T}_{1}{ }^{*}$ & $\mathrm{~T}_{2}{ }^{*}$ & $T_{3} \dagger$ & $T_{4} \dagger$ & $T_{b} \dagger$ & $T_{6} \dagger$ & $T_{7} t$ \\
\hline $\begin{array}{l}\text { Systolic BP mean } \\
\text { torr S.E.M. } \\
\text { Diastolic BP mean } \\
\text { torr S.E.M. } \\
\text { Heart rate mean } \\
\text { beats/min S.E.M. } \\
\text { Resp. Rate mean } \\
\text { breaths/min S.E.M. } \\
\text { Min. Volume mean } \\
\text { l/min S.E.M. }\end{array}$ & $\begin{array}{r}124 \\
3 \\
74 \\
2 \\
82 \\
2 \\
19 \\
<1 \\
6.7 \\
0.12\end{array}$ & $\begin{array}{r}129 \\
3 \\
77 \\
2 \\
81 \\
2 \\
18 \\
<1 \\
6.4 \\
0.15\end{array}$ & $\begin{array}{r}142 \\
3 \\
87 \\
2 \\
88 \\
2 \\
12 \\
<1 \\
8.1 \\
0.18\end{array}$ & $\begin{array}{r}140 \\
3 \\
83 \\
2 \\
83 \\
2 \\
14 \\
<1 \\
6.7 \\
0.45\end{array}$ & $\begin{array}{r}138 \\
3 \\
84 \\
2 \\
79 \\
2 \\
21 \\
<1 \\
7.4 \\
0.53\end{array}$ & $\begin{array}{r}134 \\
3 \\
83 \\
2 \\
79 \\
2 \\
21 \\
<1 \\
7.8 \\
0.51\end{array}$ & $\begin{array}{r}135 \\
3 \\
81 \\
2 \\
80 \\
2 \\
21 \\
<1 \\
8.0 \\
0.35\end{array}$ \\
\hline \multicolumn{3}{|c|}{$\begin{array}{l}\mathrm{T}_{1}=\text { prior to preop. medication } \\
\mathrm{T}_{2}=\text { pre-induction. } \\
\mathrm{T}_{8}=30 \text { min after induction. } \\
\mathrm{T}_{4}=\text { at end of anaesthesia } \\
\text { ausculatory blood pressure (wi } \\
\text { fintra-arterial blood pressure ( }\end{array}$} & \multicolumn{4}{|c|}{$\begin{array}{l}\mathrm{T}_{5}=30 \mathrm{~min} \text { after anaesthesia. } \\
\mathrm{T}_{6}=60 \mathrm{~min} \text { after anaesthesia. } \\
\mathrm{T}_{7}=120 \mathrm{~min} \text { after anaesthesia. }\end{array}$} & \\
\hline
\end{tabular}


TABLE V

Rate of Recovery after ANaesthesia (in Mins)

\begin{tabular}{lr}
\hline \hline Signs & \\
Spontaneous breathing* & 5.7 \\
Open eyes on command & 11.9 \\
Protrude tongue on command & 21.9 \\
Raise head on command & 24.7 \\
\hline
\end{tabular}

*Thirty-six patients were given prostigmine and atropine (2:1); two of these also subsequently received naloxone.

TABLE VI

Summary of Artertal Blood pH and Blood Gases Before and After Balanced ANAESTHESIA

\begin{tabular}{|c|c|c|c|c|}
\hline & $\begin{array}{c}\text { Before } \\
\text { anaesthesia }\end{array}$ & $\begin{array}{l}30 \text { min after } \\
\text { anaesthesia }\end{array}$ & $\begin{array}{l}60 \mathrm{~min} \text { after } \\
\text { anaesthesia* }\end{array}$ & $\begin{array}{l}24 \text { hrs after } \\
\text { anaesthesia }\end{array}$ \\
\hline $\begin{array}{l}\text { pH mean } \\
\text { S.E.M. } \\
\text { Range }\end{array}$ & $\begin{array}{c}7.43 \\
0.01 \\
7.34-7.55\end{array}$ & $\begin{array}{c}7.37 \\
0.01 \\
7.27-7.51\end{array}$ & $\begin{array}{c}7.39 \\
0.01 \\
7.29-7.52\end{array}$ & $\begin{array}{c}7.46 \\
0.01 \\
7.31-7.52\end{array}$ \\
\hline $\begin{array}{l}\mathrm{PaCO}_{2} \text { mean } \\
\text { S.E.M. } \\
\text { Range }\end{array}$ & $\begin{array}{l}36 \\
0.6 \\
23-47\end{array}$ & $\begin{array}{l}39 \\
0.7 \\
28-47\end{array}$ & $\begin{array}{l}37 \\
0.8 \\
21-48\end{array}$ & $\begin{array}{l}35 \\
0.7 \\
26-53\end{array}$ \\
\hline $\begin{array}{l}\mathrm{Pao}_{2} \text { mean } \\
\mathrm{S.E.M} \text {. } \\
\text { Range }\end{array}$ & $\begin{array}{l}85 \\
2 \\
61-145\end{array}$ & $\begin{array}{l}122 \\
\quad 7 \\
66-257\end{array}$ & $\begin{array}{l}134 \\
8 \\
71-298\end{array}$ & $\begin{array}{l}78 \\
3 \\
54-142\end{array}$ \\
\hline $\begin{array}{l}\mathrm{SaO}_{2} \text { mean } \\
\text { S.E.M. } \\
\text { Range }\end{array}$ & $\begin{array}{l}95 \\
<1 \\
88-99\end{array}$ & $\begin{array}{l}97 \\
<1 \\
90-100\end{array}$ & $\begin{array}{l}97 \\
<1 \\
88-100\end{array}$ & $\begin{array}{l}95 \\
<1 \\
82-100\end{array}$ \\
\hline
\end{tabular}

*During administration of $30 \%$ oxygen by Venturi-mask or nasal oxygen $(\sim 7 \mathrm{l} / \mathrm{min})$.

No conjunctival changes were observed during the anaesthetics and the pupils were usually slightly contracted and fixed in the midline.

In evaluating the respiratory response to this anaesthetic technique, all but two patients recovered normal breathing without unusual supportive measures (see Table V). Thirty-six patients were given atropine and neostigmine at the end of their operations to reverse what was judged and shown with a respirometer to be a persistent effect of pancuronium. Another $17 \mathrm{did}$ not require reversal. Two patients required naloxone in addition to reversal of the muscle relaxant. Arterial blood-gas analyses are summarized in Table VI. All patients had a mild respiratory alkalosis during the operations and the oxygen tension was usually over 100 torr. Considerable blood shunting in the lungs was evident from the $\mathrm{Pa}_{\mathrm{O}_{2}}$ estimations in several of the elderly patients. However, this is a regular observation in patients with emphysema and in those with chronic obstructive lung disease. ${ }^{11}$

\section{Postanaesthetic Effects}

In the recovery room, it was noted that the complaint of post-operative pain was far less frequent after these operations than when similar procedures were performed with inhalation anaesthetics such as enflurane and halothane. Only three patients required potent analgesic medication within the first 30 minutes in the recovery room and nine others in the following two hours. The incidence of nausea and vomiting was 26 per cent. Of this percentage, 7 per cent vomited. Other side-effects are listed in Table VII. 
TABLE VII

Postanaesthetic Side Effects

\begin{tabular}{lc}
\hline \hline Symptoms & No. of patients \\
$(\%)$
\end{tabular}

TABLE VIII

Subjective Answers Related to Operation (INTERVIEWED FIRST POSTOP. DAY)

\begin{tabular}{lcc}
\hline \hline & Yes & No \\
\hline $\begin{array}{l}\text { Remembers going to } \\
\text { operating room }\end{array}$ & $51(96 \%)$ & $2(4 \%)$ \\
$\begin{array}{l}\text { Remembers moving to } \\
\text { operating table }\end{array}$ & $46(86 \%)$ & $7(14 \%)$ \\
Remembers going to sleep & $27(50 \%)$ & $25(50 \%)$ \\
$\begin{array}{l}\text { Remembers being in } \\
\text { recovery room }\end{array}$ & $21(10 \%)$ & $32(60 \%)$ \\
"Sleep" pleasant* & $21(40 \%)$ & $\mathbf{4 ( 8 \% )}$ \\
\hline
\end{tabular}

*Twenty-eight patients $(52 \%)$ had no memory of event.

Fifty patients received one or more drugs during the 24 hours after return to the ward, as follows: for analgesia, meperidine, 40 times; morphine, 12; levodromoran, 1; acetaminophen, 1; percodan, 1; for nausea or vomiting, proclorperazine, 9; trimethobenzamide, 3 ; hydroxyzine, 4 . Three patients were given diazepam for sedation and one received diphenhydramine for a minor transfusion reaction. Most of the patients received antibiotics as well.

At interview, the day following the operation, it was observed that some patients had amnesia for the immediate pre-operative events, none recalled anything of the operation and many did not remember being in the recovery room (see Tables VIII and IX). All but two patients were pleased with the anaesthetic they had received.

The results of laboratory tests were similar to those reported after evaluation of numerous combinations of analgesics with sedatives in animal tests and after use

TABLE IX

Patients' Evaluation of Anaesthetic (INTERVIEWED ON FIRST POSTOP. DAY)

\begin{tabular}{lccc}
\hline \hline & & \\
Time to fall asleep & Long & Short & Can't \\
& 0 & $38(72 \%)$ & remember \\
Recall induction & Yes & Vague & $15(28 \%)$ \\
& $3(6 \%)$ & $39(74 \%)$ & No \\
Recall operative events - none & & $11(21 \%)$ \\
\hline
\end{tabular}


of pentazocine and other analgesics for balanced anaesthesia in man. ${ }^{12-16}$ All the patients in this study survived their operations.

\section{Summary and Conclusions}

After premedication with diazepam and antisialogogues, butorphanol tartrate was used with thiopentone and pancuronium to induce surgical anaesthesia. The induction was smooth in all cases. Nitrous oxide (65 per cent) was used with supplementary small doses of butorphanol tartrate and pancuronium to maintain satisfactory conditions for major abdominal operations in 53 consenting patients. Respiration was invariably controlled with a mechanical respirator. Blood pressure was slightly elevated, pulse rate was stable, and the electrocardiogram was essentially unchanged (lead II) in the majority of patients.

Recovery of adequate respiration was uneventful after reversal of the residual effects of pancuronium. Neostigmine and atropine were the reversal agents. Two patients were given naloxone as well, to reverse excessive drowsiness and respiratory depression apparently due to butorphanol tartrate.

The incidence of other side-effects, such as nausea and vomiting, was not excessive. Amnesia for surgical events was complete in all cases and most of the patients were pleased with the anaesthetic management.

Since butorphanol tartrate provides satisfactory analgesia for major surgery, is available synthetically, has a low propensity to addiction, and has little or no effect on the cardiorespiratory system or on liver and kidney function, we recommend further trial of this compound when a parenteral form of balanced anaesthesia is desired.

\section{RÉSUMÉ}

Après une prémédication avec diazepam, atropine ou scopolamine, le tartrate de butorphanol a été utilisé avec le thiopentone et le pancuronium pour induire l'anesthésie. Celle-ci, dans les 53 cas étudiés, a été maintenue avec du protoxyde d’azote et de petites doses supplémentaires de tartrate de butorphanol et de pancuronium. Dans tous les cas, la respiration était contrôlée mécaniquement.

La tension artérielle était légèrement augmentée. La fréquence cardiaque est demeurée stable et l'électrocardiogramme n'était pas modifié dans la majorité des patients. Le retour à une respiration adéquate a été obtenu après neutralisation des effets du pancuronium par néostigmine et atropine; la naloxone a été employée chez deux patients pour renverser une somnolence marquée et une dépression respiratoire probablement secondaire au tartrate de butorphanol.

L'incidence d'effets secondaires, tels nausée ou vomissement, était basse. Une amnésie de la procédure chirurgicale entière a été confirmée chez tous les patients.

En raison au niveau d'analgésie qu'il procure, de sa faible tendance à produire de l'accoutumance et de son peu d'influence sur les systèmes cardiorespiratoire, hépatique et rénal, nous recommandons l'essai du tartrate de butorphanol quand une forme parentérale d'anesthésie balancée est désirée.

\section{ACKNOWLEDGMENTS}

The authors are grateful to Barbara Esposito, R.N., Peggy Duchessi, R.N. and the nursing staff in the recovery room for their able assistance, and for their careful 
recording of the patient interviews. This study was supported by a grant from Bristol Laboratories, Syracuse, New York.

\section{REFERENCES}

1. Dobkin, A.B., Eamkaow, S., Zak, S., \& Caruso, F.S. Butorphanol: a double-blind evaluation in post-operative patients with moderate or severe pain. Canad. Anaesth. Soc. J. 21: 600 (1974).

2. Dobkin, A.B., Eamikaow, S., \& Caruso, F.S. Butorphanol and pentazocine in patients with severe post-operative pain. Clin. Pharmacol. \& Therap. 18: 547 (1975).

3. Tavakoli, M., Conssen, G., \& Caruso, F.S. Butorphanol and Morphine: A double-blind comparison of their parenteral analgesic activity. Anesth. \& Analg. 55: 394 (1976).

4. Gilbeht, M., Hanover, R., Moylan, D., \& Caruso, F.S. Intramuscular butorphanol and meperidine for analgesia in post-operative pain. Unpublished report on file with Bristol Laboratories (1976).

5. Foldes, F.F., Nagashima, H., Karamanian, A.V., Radney, P., Malovany, R., Koerner, S., \& ANG, M. Double-blind comparison of the respiratory and circulatory effects of intravenous butorphanol and morphine. Proc. of 37th Ann. Scientific Meeting of Committee on Problems of Drug Dependence, pp. 373-390 (1975).

6. Doвkin, A.B. Double-blind comparison of the effects 'of butorphanol tartrate ( $3 \mathrm{mg}, \mathrm{I} . \mathrm{V}$. ) and morphine sulphate $(15 \mathrm{mg}, \mathrm{I} . \mathrm{V}$.) on plasma histamine levels. Unpublished study report on file with Bristol Laboratories (1975).

7. Gensini, G.G. Single-blind comparison of effect of intracardiac injection of butorphanol tartrate $(0.02 \mathrm{mg} / \mathrm{kg})$ and morphine sulphate $(0.1 \mathrm{mg} / \mathrm{kg})$ on circulatory dynamics. Unpublished study - report on file with Bristol Laboratories (1975).

8. Dobrin, A.B., Africa, B.F., Noveck, R.J., Caruso, F.S., Espostto, B., \& Smonds, J. Butorphanol tartrate: 1. Safety and efficacy in multi-dose control of post-operative pain. Cdn. Anaesth. Soc. J. 23: 596 (Nov. 1976).

9. Dobkin, A.B., Ishael, J.S., Evers, W., \& Bisset, C.M. Double-blind evaluation of diazepam for premedication. Canad. Anaesth. Soc. J. 17: 52 (1970),

10. Vanbergen, F.H., Weatherhead, D.S., Theloar, A.E., Dobkin, A.B., \& Bucklex, J.J. Comparison of indirect and direct methods of measuring arterial blood pressure. Circulation 10: 481 (1954).

11. WEST, J.B. Ventilation/blood flow and gas exchange. Blackwell scientific publications, 2nd ed., Oxford (1970).

12. DobkiN, A.B., Lee, P.K.Y., \& Byles, P.H. Neuroleptanalgesics: 2. Laboratory Evaluation of Combination of Analgesics and Neuroleptics with Nitrous Oxide. Canad, Anaesth. Soc. J. 12: 39 (1965).

13. Doвкіn, A.B. The interaction of inhalation anesthetics with sedatives and hypnotics. Anaesthesiology and Resuscitation 90: 245 (1975).

14. Dobkin, A.B., Levy, A.A., Ounkasem, K., \& Pieloch, P.A. The metabolic response to methotrimeprazine used as a supplement to balanced anaesthesia for major abdominal surgery. Progress in Anaesthesiology: Proceedings of the Fourth World Congress of Anaesthesiologists, pp. 1197-1202, London (1968).

15. Dobkin, A.B., Ismael, J.S., \& Pieloch, P.A. The metabolic response to pentazocine as a supplement to balanced anaesthesia for major abdominal surgery. Canad. Anaesth. Soc. J. $17: 485(1970)$.

16. Dobkin, A.B., Pifloch, P.A., Isnael, J.S., \& Neville, J.F., Jr. Circulatory and metabolic effects of innovar-fentanyl-nitrous oxide anaesthesia for abdominal surgery in man. Anesth. \& Analg. 49: 261 (1970).

AdDEndum: Since submitting this report an additional 22 patients have been studied in a similar fashion, including 14 patients who had major abdominal operations and 8 patients who had heart surgery (coronary grafts). The latter received a mean dose of $14 \mathrm{mg}$ butorphanol and were skillfully managed by Dr. D. King. All these additional patient studies were uneventful and the patients have a smooth postoperative course. 